\title{
ÇALIŞANLARIN KURUMSAL SOSYAL SORUMLULUK ALGILARININ DEMOGRAFİK DEĞİŞKENLER AÇISINDAN İNCELENMESI
}

\author{
Araş. Gör. Dr. Rıza DEMIR* \\ Araş. Gör. Erman TÜRKMEN**
}

\begin{abstract}
ÖZET
Kurumsal sosyal sorumluluk (KSS), genel olarak örgütlerin iç ve dış çevresine karşı sorumlu davranmasın ifade eden bir kavram olarak tanımlanabilir. 1980'li yılların başlarında “işletmelerin ekonomik faaliyetlerinin onunla ilgili tarafların (hissedarlar, çalışanlar, tüketiciler ve tüm toplumun) hiçbirinin menfaatlerine zarar verilmeden yönetilmesi" olarak tanımlanan KSS'nin, günümüzde etik ve gönüllü sorumlulukları da kapsadiğg söylenebilir. Çalışanların örgütlerinin KSS'ye ve KSS'nin alt boyutlarına yönelik algılarının demografik değişkenler açısından incelenmesinin amaçlandı̆̆ı bu çalışmada, anket yöntemi kullanılarak özel sektörden ve kamu sektöründen 241 kişi kapsamında yapılan bir saha araştırmasının sonuçlarına yer verilmişstir. Araştırma sonucunda katılımcıların, örgütlerinin KSS'nin ekonomik, yasal, etik ve gönüllü sorumluluk olmak üzere bazı alt boyutlarına yönelik algılarının cinsiyet, medeni durum, eğitim, çalışılan sektör, yaş ve toplam çalışma süresi açısından farklılık gösterdiği belirlenmiştir.
\end{abstract}

Anahtar Kelimeler: Kurumsal Sosyal Sorumluluk (KSS), Gönüllü Sorumluluklar, Demografik Değişkenler.

JEL Sinıflandırması: M12, O15, D23

\section{EXAMINATION OF CORPORATE SOCIAL RESPONSIBILITY PERCEPTION OF EMPLOYEES IN TERMS OF DEMOGRAPHIC VARIABLES}

\begin{abstract}
Corporate Social Responsibility (CSR) can be defined as operating the organizations responsibly to internal and external environment. In the early 1980's, CRS used to mean to manage activities of organizations without detriment to parties such as shareholders, employees, consumers and society, now it includes ethical and discretionary (philanthropic) responsibilities. This study aims to examine the perception of employees about corporate social responsibility in terms of demographic variables. The survey method was used in study. The sample consisted of 241 employees from private and public sector organizations. The results indicate that there are significant differences in employees' perception of corporate social responsibility according to gender, marital status, education, sector, age and seniority.
\end{abstract}

\footnotetext{
* İstanbul Üniversitesi, İșletme Fakültesi, İnsan Kaynakları Yönetimi Anabilim Dalı, rdemir@istanbul.edu.tr

** İstanbul Üniversitesi, İşletme Fakültesi, İnsan Kaynakları Yönetimi Anabilim Dalı, eturkmen@istanbul.edu.tr
} 
Key Words: Corporate Social Responsibility (CSR), Discretionary (Philanthropic) Responsibilities, Demographic Variables.

JEL Classification: M12, O15, D23

\section{GİRIŞ}

Kurumsal Sosyal Sorumluluk (KSS) kavramı, özellikle son yıllarda iş hayatında kendinden fazlaca söz ettiren bir kavram olarak dikkat çekmektedir. Sosyal sorumluluk anlayışının önem kazanmasıyla birlikte işletmeler, bugün ekonomik faaliyetleri yanında farklı alanlarda da sorumluluklar üstlenmektedir. Günümüz itibariyle işletmelerden, iş faaliyetlerinin çalışanlar, hissedarlar, tedarikçiler, müşteriler vb. tüm paydaşları etkilemesi nedeniyle, kâr elde etmenin yanında, toplumdaki sorunlara karşı duyarlı olmaları ve yasal düzenlemelere, etik kurallara ve sosyal çevreye önem vermeleri beklenmektedir. Bireyler ve tüketiciler açısından bakıldığında, sosyal ve çevresel sorumlulukların, bir işletmenin itibar kazanmasını etkileyen önemli faktörler olduğu görülmektedir. Yapılan araştırmalarda da farklı konulara yönelik sosyal sorumluluk uygulamalarının giderek önem kazandığı, işletmelerin sivil davranışlarını gösteren bu tür faaliyetlerin paydaşlar tarafından daha fazla talep edildiği tespit edilmektedir. Günümüzde işletmelerin, ekonomik faaliyetlerde bulunarak kâr elde etme amacı yanında, toplum için faydalı işler yapmanın da önemini kavramış oldukları; sosyal sorumluluk faaliyetlerinde bulunmaları durumunda paydaşlar tarafindan daha olumlu karşılanacaklarını düşündükleri söylenebilir.

Çalışmada öncelikle kurumsal sosyal sorumluluk kavramı ve kurumsal sosyal sorumluluğun boyutları tanımlanmaya çalışılmış; sonrasında ise çalışanların örgütlerinin kurumsal sosyal sorumluluğuna yönelik algılarının bazı demografik özelliklere göre farklılaşıp farklılaşmadığını inceleyen araştırma sonuçlarına yer verilmiştir. Çalışmanın ikinci kısmında ise, kamu sektöründe ve özel sektörde çalışan bireylerin örgütlerine yönelik KSS ve KSS'nin alt boyutlarına ilişkin algılarının, bazı demografik özelliklerine göre değişip değişmediğinin belirlenmeye çalışıldığı araştırmanın sonuçlarına yer verilmiştir. 241 kişi üzerinde gerçekleştirilen araştırma ile, katılımcıların ilgili konulara yönelik algılarının demografik özelliklerine göre farklılık gösterip göstermediğine ilişkin ayrıntılı sonuçlar elde edilmiştir.

İşletmelerin KSS faaliyetlerine verdikleri önem yanında, örgütlerin KSS'ye yönelik faaliyetlerinin çalışanları tarafından nasıl algılandığı da önemli görülmektedir. Çünkü KSS'yle ilgili sorumluluklarını yerine getirmeye çalışan bir işletmenin konuyla ilgili uygulama ve faaliyetleri çalışanları tarafından doğru algılanmayabilir ya da çalışanların farklı demografik özelliklere sahip olmaları nedeniyle, KSS'nin ekonomik, yasal, etik ve gönüllü sorumluluk boyutlarına yönelik düşünce ve beklentileri farklılık gösterebilir. Çalışanların demografik özelliklerine göre örgütlerinin KSS'ye ilişkin algılarında farklılık bulunması durumunda; söz konusu farklılıklar doğrultusunda yöneticilerin, 
kadınlar, gençler, daha az kıdemliler ya da eğitim düzeyi yüksek olanlar gibi belirli grup çalışanların KSS algılarını kuvvetlendirecek şekilde bazı boyutlara yönelik uygulama ve faaliyetlere ağırlık vermesi ya da gerçekleştirilen faaliyetlerin tanıtımının daha iyi yapılması gerekebilir. İşletmeler, özellikle çalışanlarına yönelik KSS'yle ilgili sorumluluklarını yerine getirirken, KSS'ye yönelik algılar için demografik özelliklerden kaynaklanan farklılıkları göz önünde bulundurulabilir. Algılardaki farklılıkları öğrenmek, KSS hedeflerinin doğru konulmasına, uygulamalardaki olası yanlışlıkların düzeltilmesine, iletişimdeki eksik kalan noktaların görülmesine ve yeni düzenlemeler yapılmasına olanak sağlayacaktır. Bunun yanında çalışanların KSS'ye yönelik algıları ile ilgili ülkemizde az sayıda çalışma yapılmış olmasının araştırmayı önemli kıldığı düşünülmektedir.

\section{KAVRAMSAL ÇERÇEVE}

\subsection{Kurumsal Sosyal Sorumluluk Kavramı ve Boyutları}

Örgütlerin ekonomik faaliyetlerinde ilişki kurmak zorunda olduğu taraflarla ve kanun koyucularla olan bağlarının ve sorumluluklarının tanımlanması amacıyla tarihsel süreç içerisinde farklı tanımlamalar yapılmış ve teoriler geliştirilmiştir. J.M. Clark 1916 yılında yayımlanan makalesinde çalışanların faaliyetleri karşılığında elde ettikleri sonuçlardan sorumlu olmaları durumunda, kurumsal sorumlulukların da iş ilişkilerine yönelik yasal olarak yerine getirilmesi zorunlu olan ya da olmayan bazı davranışları içermesi gerektiğini belirtmektedir (CR Theoretical Background). 1930'ların başında Theodore Kreps, örgütlerin sosyal sorumlulukları konusunda ilk kez "sosyal denetim" kavramını kullanmış, Peter Drucker ise 1942 yılında yayınladığı kitabında örgütlerin ekonomik amaçlar kadar sosyal boyuta da önem vermesi gerektiğini belirterek sorumluluk kavramı ve özgürlüğün korunması konuları üzerinde durmuştur.

1953 y1lında Howard Bowen, kurumsal sosyal sorumluluk (KSS) konusunda modern zaman literatürünün başlangıcı olarak kabul edilen "İşadamının Sosyal Sorumluluğu" adlı kitabında KSS kavramından bahsetmektedir. Bowen'a göre KSS; toplumun hedefleri ve değerleri açısından istenen politikaları izlemek, uygun kararları almak ya da ilgili faaliyetleri takip etmek için örgütler tarafından üstlenilmesi gereken yükümlülüklerdir (Crane vd., 2008: 25). Bowen toplum hedefleri ile örgütün sosyal bir anlaşma çerçevesinde toplumun memnuniyeti için varolduğunu (social contract), toplum değerleri ile de örgütün toplum içindeki ahlâklı duruşunu (moral agent) kastetmektedir (Andriof, 2002: 21). Keith Davis 1960 yılında yayımladığg makalesinde örgütün KSS'si ile toplumdaki gücü arasındaki ilişkiyi ortaya koymuş ve "örgütler, niçin KSS'lerini yerine getirmek zorundadır?", "sosyal sorumluluklarının ne yönde olacağını nasıl bilirler?" ve "yükümlü oldukları sorumlulukları yerine getirmezlerse neler olabilir?" şeklinde üç temel soruya cevap arayarak hem KSS'nin örgütün toplumdaki gücüne etkisini incelemiş hem de örgütlerin kararlarında sosyal sorumluluklarını göz önünde bulundurmaları durumunda yapması gerekenleri belirtmiştir (Davis, 1960: 70). 
Bahsedilenlerin yanı sıra KSS kavramına ilişkin literatürde çeşitli tanımlar bulunmaktadır. KSS, İngiliz Parlamento üyesi Nigel Griffiths'e göre örgütün faydalarını maksimize, zararlarını ise minimize etmeye çalışırken yerine getirdiği faaliyetlerin ekonomik, sosyal ve çevresel etkilerinin dikkate alınmas1; Dünya Sürdürülebilir Kalkınma İş Konseyi (WBCSD)'ne göre, büyük ölçekte halkın ve toplumun olduğu kadar işgücünün ve ailelerin yaşam kalitesini geliştirirken etik davranma ve ekonomik gelişmeye katkıda bulunma konularında işletmeler tarafından sürdürülen bağl1lık; Avrupa Birliği'ne göre örgütlerin faaliyetlerinde ve paydaşlarla olan ilişkilerinde gönüllük esasına göre sosyal ve çevresel sorunları ele alması; ILO'ya göre ise işletmelerin yasal yükümlülüklerinin ötesinde üstlendikleri gönüllü girişimler olarak tanımlanmaktadır (Hopkins, 2012: 24-26). Avrupa Komisyonu tarafından yapılan tanımda da KSS işletmelerin faaliyetlerinde ve paydaşlarıyla etkileşimlerinde gönüllü olarak sosyal ve çevresel kaygıları taşıdıklarını gösteren bir kavram olarak ifade edilmektedir (Ilic, 2010: 305). KSS, herhangi bir organizasyonun hem iç hem de diş çevresindeki tüm paydaşlara karşı "etik" ve "sorumlu" davranmasını, bu yönde kararlar almasını ve uygulamasını ifade eden bir kavramdır (Aktan ve Vural, 2007: 4). Sosyal sorumluluk kavramının sözlük anlamının, toplumla ilgili konularda yüklenilen işten ve görevden ötürü gerektiğinde hesap verme durumu olduğu da söylenebilir (Yönet, 2005: 241). KSS, "işletmenin sürdürülebilir ekonomik gelişmeye olan katkısı, çalışanlar, aileleri ve tüm toplumun yaşam kalitesini arttırmaya olan bağlılığı” olarak da tanımlanabilir.

KSS'nin ihtiyaçlar hiyerarşisi çerçevesinde ele alındığı bir çalışmada KSS'si olan bir örgüt, tüm ihtiyaçları güçlü bir şekilde karşılayan ve ihtiyaçlar hiyerarşisine göre kendini gerçekleştiren bir örgüt olarak belirtilmektedir. Bu işletmeler, tüm paydaşlarının refahı için gönüllü olarak katkıda bulunan ve bu nedenle imrenilen pozisyonda olan örgütlerdir (Tuzzolino and Armandi, 1981: 23).

KSS, işletmelerin ya da iş çevresinin toplumdaki rolünü incelemeyi ve işletmeler tarafindan yerine getirilen faaliyetler sonucu oluşan toplumsal çıktıları maksimize etmeyi amaçlamaktadır. "Toplumda işletmelerin rolü nedir?" ya da "işletmeler ne için vardır?" sorusuna "işletmeler hissedarlarına kâr sağlamak ve bu kârlılıkla toplumsal refaha katkıda bulunmak için vardır" şeklinde cevap veren Milton Friedman ve Hissedarlar Paradigmasına bir tepki olarak, günümüzde hissedarlar haricinde diğer paydaşlara yönelik sorumlulukları da barındıran bir KSS anlayışına geçiş söz konusudur (Akbaş, 2010: 20). Bu doğrultuda bugünkü KSS paradigmasının günümüzde hissedarlarla birlikte içinde bulunduğu toplumun geneline yönelik sorumlulukları kapsadığı ve işletmeleri toplumdan ayrı değil, toplumun bir parçası olarak kabul ettiği söylenebilir (Boeger, 2008: 9).

KSS konusunda paydaşlar genellikle hissedarlar, çalışanlar, müşteriler, alacaklılar (özellikle kredi veren bankalar), tedarikçiler, sendikalar, rakipler, hükümetler, yerel topluluklar ve genel toplumdur (Sims, 2003: 41). Bununla birlikte literatürde KSS ile ilgili pek çok teorinin olduğu söylenebilir. Teoriler genellikle KSS'nin ilgili olduğu paydaşlara ya da önem verdiği sosyal veya ahlâki değerlere göre değişmektedir. Uzun dönemde örgütlerin toplumun refahı için sağladığı katkının yeterliliği ve örgütün hissedarları ile örgüt - toplum arasındaki ilişki KSS konusunda iki önemli etken 
olarak görülmektedir (Paetzold, 2010: 7). Friedman, Sethi, Carroll ve Elkington gibi yazarlar söz konusu etmenler açısından farklı teoriler geliştirmişlerdir.

Yukarıda da belirtildiği üzere Friedman, KSS'yi işletmenin kârlılığını artırmak için sadece bir araç olarak görmekte ve tüm sosyal ve çevresel faaliyetleri devlet ve toplumla ilişki kurabilmek için yerine getirilmesi zorunlu işler olarak düşünmektedir (Friedman, 1970).

S. Prakash Sethi tarafından 1975 yılında geliştirilen modelde ise KSS, sosyal yükümlülük, sosyal sorumluluk ve sosyal duyarlılık olmak üzere üç boyutta incelenmiş̧ir. Modelde örgütün davranış boyutları olarak yasal durum, etik normlar, hesap verebilirlik, kurum stratejileri, sosyal baskılara tepkiler, hükümetle ilişkilere yönelik faaliyetler, mevzuata ve politikaya yönelik faaliyetler ve hayırseverlik ele alınmaktadır. Kurumsal davranışın sınıflandırılmasında kullanılan boyutlardan sosyal yükümlülük yasal olarak ve piyasa koşulları açısından olası zorunlulukları, sosyal sorumluluk toplumsal normları, değerleri ve performans beklentilerini, sosyal duyarlılık ise sosyal ihtiyaçlara yönelik ileriye dönük ve önleyici faaliyetleri ifade etmektedir (Sethi, 1975: 60-63).

Sethi'nin modelini geliştirerek kendi teorisini ortaya koyan Archie Carroll, KSS'yi ekonomik, yasal, ahlâki ve gönüllü sorumluluklar başlıkları altında dört boyutta incelemiştir (Carroll, 1991). Ekonomik sorumluluklar, tüketicilerin ihtiyaç duyduğu ve talep ettiği mal veya hizmetlerin üretilmesi ve kabul edilebilir miktarda kârın sağlanmasını; yasal sorumluluklar örgütlerin faaliyetlerini gerçekleştirirken yasal yükümlülükleri yerine getirmesini; etik sorumluluklar tüketicilerin, çalışanların, hissedarların ve toplumun örgütlerden beklediği ve yasalarda yer almayan standartları, normları ve davranışları; gönüllü sorumluluklar ise örgütün toplum üzerindeki olumlu algılarını artıran ve iyi bir vatandaş olarak değerlendirilmesi sağlayan faaliyetleri ifade etmektedir (Carroll, 1991: 4142). Elkington ise KSS'yi 1997 yılında geliştirdiği “Üçlü Kâr Hanesi (The Triple Bottom Line)" ile açıklamaktadır. Çevrenin korunması, sosyal kapsayıcılığın gelişmesi ve istihdam bakımından sağlıklı bir ekonomik büyümenin oluşması olarak ifade edilebilecek üçlü kâr hanesi yaklaşımı doğrultusunda Elkington KSS'yi çevre bilimi, sosyal değer ve ekonomik değer olmak üzere üç boyutta incelemektedir (Paetzold, 2010: 7).

Özetlemek gerekirse KSS'nin; örgütlerin kârlılıklarına önem verdikleri kadar çalışanlarına, müşterilerine, tedarikçilerine, rakiplerine, devlete ve topluma karşı sorumlu davranmaları gerektiğini belirten, söz konusu sorumlulukları genel olarak ekonomik, yasal, etik ve hayırseverlik başlıkları altında inceleyen, özellikle son yıllarda kapsamı genişleyen ve önemi artan bir kavram olduğu söylenebilir.

\section{2. Çalışanların KSS Algılarının Demografik Değişkenler Açısından İncelenmesi}

Kısaca örgütlerin iç ve dış çevresine karşı sorumlu davranmasını ifade eden KSS doğrultusunda işletmelerin, günümüzde toplum, çevre, eğitim ve sağl1k gibi alanlarda, özellikle gönüllülüğe dayalı 
projelere yer verdikleri görülmektedir. Türkiye'de de işletmelerin KSS'yi, daha çok gönüllü uygulamalar kapsamında örgütlerinin itibarına yönelik kurumsal iletişim projeleri düzeyinde uyguladığı söylenebilir. Vaka çalışması yöntemi kullanılarak on holding kapsamında gerçekleştirilen araştırma sonucunda; örgütlerin KSS'ye ilişkin uygulama ve söylemlerinin öncelikli olarak KSS'nin en önemli hedef kitlesi olan çalışanlara ve sonra sırasıyla müşterilere, topluma ve çevreye yönelik olduğu ve KSS faaliyetlerinin en çok eğitim, kültür/sanat ve spor alanlarında görüldüğü tespit edilmiş ve KSS faaliyetlerinin uygulanması konusunda holdingler arasında kurumsal bir eşbiçimlilik (birbirine benzeme) olduğu gözlenmiştir (Dinçer ve Özdemir, 2013: 57). Yapılan bir başka araştırmanın sonucunda ise araştırmaya katılan şirketlerin büyük bir çoğunluğu, ilgili KSS faaliyetlerinin kurumsal yararları olduğunu kabul etse de toplumsal yararlarının kurumsal yararlarından fazla olduğunu düşünmektedir (Sert, 2012: 31).

Bununla birlikte işletmelerin KSS faaliyetlerine verdikleri önem yanında, örgütlerin KSS'ye yönelik faaliyetlerinin çalışanları tarafindan nasıl algılandığı da önemli görülmektedir. Keza bir işletmenin yalnızca KSS'yle ilgili sorumluluklarını yerine getirmesinin yeterli olmadığı, halkla ilişkiler vb. birimlerin desteğiyle doğru iletişim kurularak KSS'ye yönelik faaliyetlerin daha iyi anlaşılmasına katk1 sağlanacağı söylenebilir. İşletmelerde halkla ilişkiler birimlerinin yaptığı alg1 araştırmaları işletmelerin KSS hedeflerini doğru koymasına, uygulamalardaki olası yanlışlıkları düzeltmesine, iletişimdeki eksik kalan noktaları görmesine ve buna yönelik yeni düzenlemeler yapmasına olanak sağlamaktadır (Bıçakçı, 2011: 27).

Örgütlerin KSS'ye ve KSS'nin alt boyutlarına yönelik faaliyetlerine ilişkin algıların, çalışanların farklı demografik özelliklerine göre değişebileceği düşünülmektedir. İlgili literatür incelendiğinde, KSS'nin ekonomik, yasal, etik ve gönüllülük boyutlarına yönelik çalışan algılarının bazı demografik özelliklere göre farklılaştığı sonucuna ulaşan araştırmalar olduğu gibi, KSS'ye yönelik algıların demografik özelliklere göre farklılaşmadığını ortaya koyan araştırmalar olduğu da görülmektedir. Çalışmanın bu kısmında, cinsiyet, medeni durum, eğitim, çalışılan sektör, yaş ve toplam çalışma süresi değişkenleri açısından, çalışanların örgütlerinin KSS'ye ve KSS'nin alt boyutlarına yönelik algılarının farklılaşıp farklılaşmadığını inceleyen bazı araştırma sonuçlarına yer verilmiş ve ilgili demografik özelliklere göre KSS'ye yönelik algılar arasında farklılık olup olmadığı, aşağıda geliştirilen hipotezler ile test edilmeye çalışılmıştır.

Demografik değişkenlerden cinsiyet değişkeni açısından KSS'ye yönelik algılarda farklılık olup olmadığını inceleyen araştırmaların çoğunda farklı sonuçlara ulaşıldığı söylenebilir. Örneğin bir araştırmada, daha çok kadın çalışana sahip örgütlerde KSS boyutlarından örgüt içi prosedürel adalet ile dışsal sosyal sorumluluk boyutlarının; daha çok erkek çalışana sahip örgütlerde ise eğitim ihtiyaçlarının karşılanması boyutunun örgütsel bağlılığı daha çok etkilediği tespit edilmiştir (Brammer, Millington and Rayton, 2007: 1715). Yapılan diğer araştırmalarda ise KSS algısı ile örgütsel bağlılık arasındaki ilişkinin kadınlarda erkeklere göre daha güçlü olduğu (Stawiski, Deal ve 
Gentry, 2010: 4) ve kadın çalışanlar arasında KSS'nin gönüllülük boyutuna yönelik algı ile örgütsel bağlılık arasında daha güçlü bir ilişki olduğu belirlenmiştir (Peterson, 2004: 296). KSS'ye yönelik algılarda farklılık olup olmadığını inceleyen diğer araştırmalarda ise KSS algısının kadın çalışanlarda daha yüksek olduğu (Kelley, Ferrell ve Skinner, 1990: 681); KSS'nin "ekonomik sorumluluk" boyutunun kadınlara göre erkek çalışanlarca daha önemli algılandığı (Tan ve Komaran, 2006: 6) tespit edilmiştir. Bununla birlikte, cinsiyet açısından KSS algıları arasında farklılık olmadığını ortaya koyan çalışmalar da söz konusudur (Yam ve Fredericks, 2009: 25; Çelik, 2013: 144).

Sonuç itibariyle, cinsiyete göre KSS'ye yönelik algılarda farklılık olup olmadığını inceleyen araştırmaların çoğunda farklı sonuçlara ulaşıldığı söylenebilir. Literatürdeki bu bulgulara dayanarak KSS'ye yönelik çalışan algılarının cinsiyete göre değişeceğine ilişkin araştırma hipotezi şu şekilde kurulmuştur:

\section{$H_{1}$ : Çalışanların cinsiyetine göre kurumsal sosyal sorumluluk algılamaları farklılık göstermektedir.}

Medeni durum değişkeni açısından KSS'ye yönelik algıda farklılık olup olmadığı incelendiğinde, farklılık olmadığı sonucunu ortaya koyan araştırma söz konusu olduğu gibi (Chattananon, Lawley, 2007) KSS'nin bekar katılımcılar tarafından daha olumlu görüldügü sonucunu ortaya koyan bir çalışma mevcuttur (Virvilaite ve Daubaraite, 2011: 540). Buna karş1lık bir çalışmada da, evli çalışanların örgütlerinin KSS'ye yönelik algısının daha güçlü olduğu belirlenmiştir (Lloyd, Heinfeldt ve Wolf, 2008). Ayrıca KSS'nin marka algısına etkisinin incelendiği bir araştırmada bekâr katılımcıların evlilere göre KSS bazlı faaliyetlere daha olumlu baktıkları, özellikle marka çağrışımı ve algılanan kalite faktörleri açısından KSS bazlı faaliyetlerin markaya etkisinin bekâr katılımcılarda daha fazla olduğu belirlenmiştir (Akkoyunlu ve Kalyoncuoğlu, 2014: 142).

Literatürdeki bu bulgulara dayanarak KSS'ye yönelik çalışan algılarının medeni duruma göre değişeceğine ilişkin araştırma hipotezi şu şekilde kurulmuştur:

\section{$\mathrm{H}_{2}$ : Medeni duruma göre çalışanların kurumsal sosyal sorumluluk algılamaları farklılık göstermektedir.}

Eğitim değişkeni açısından KSS'ye yönelik algıda farklılık olup olmadığı incelendiğinde, yapılan pek çok araştırmada eğitim seviyesi daha yüksek olan çalışanların eğitim seviyesi düşük çalışanlara göre KSS'ye yönelik algılarının daha olumlu olduğu ve KSS'yi daha çok önemsedikleri görülmektedir (Virvilaite ve Daubaraite, 2011: 538; Lamsa, Vehkapera, Puttonen ve Pesonen, 2008; Quazi, 2003; Lloyd, Heinfeldt ve Wolf, 2008; Dixon-Ogbechi, Aiyeku, Haran ve Jarutirasarn, 2013). Bununla birlikte KSS algısının eğitim seviyesine göre değişmediğini ortaya koyan çalışmalar da söz konusudur (Çelik, 2013: 147; Dickson, 2001; Blundin vd., 2012). KSS'nin marka algısına etkisinin incelendiği araştırmanın sonucunda da eğitim seviyesi arttıkça, KSS faaliyetlerinin marka sadakatine olan etkisinin de arttı̆̆ tespit edilmiştir (Akkoyunlu ve Kalyoncuoğlu, 2014: 142). 
Literatürdeki bu bulgulara dayanarak KSS'ye yönelik çalışan algılarının eğitim düzeyine göre değişeceğine ilişkin araştırma hipotezi şu şekilde kurulmuştur:

\section{$H_{3}$ : Eğitim seviyesine göre çalışanların kurumsal sosyal sorumluluk algılamaları farklılık göstermektedir.}

Çalışılan sektör değişkeni açısından KSS'ye yönelik algıda farklılık olup olmadığ incelendiğinde; özellikle özel sektörde KSS'nin yasal boyutunun daha fazla önemsendiği belirlenmiştir (Tan ve Komaran, 2006: 6). Bununla birlikte kurumsal sosyal sorumluluk algılamalarının kamu veya özel kesimde çalışmaya bağlı olarak farklılık göstermediği sonucuna ulaşan bir araştırma da söz konusudur (Kaya, 2008: 107).

Literatürdeki söz konusu bulgulara dayanılarak KSS'ye yönelik çalışan algılarının çalışılan sektöre değişeceğine ilişkin araştırma hipotezi şu şekilde kurulmuştur:

\section{$H_{4}$ : Çalışılan sektöre göre çalışanların kurumsal sosyal sorumluluk algılamaları farklılık göstermektedir.}

Yaş değişkeni açısından KSS'ye yönelik algıda farklılık olup olmadığı incelendiğinde, bir araştırmada daha yaşlı olanların örgütlerine ilişkin KSS algılarının daha olumlu olduğu belirlenmiştir (Lloyd, Heinfeldt ve Wolf, 2008). Bir başka araştırmada 36-45 yaş arası olan çalışanların önemli bir kısmının, 18 yaş altı olan çalışanların ise büyük kısmının KSS'yi diğer yaş gruplarına göre daha olumlu gördüğü belirlenmiştir (Virvilaite ve Daubaraite, 2011: 539; Dixon-Ogbechi, Aiyeku, Haran ve Jarutirasarn, 2013). Diğer bir araştırmada ise 51 ve üstü yaş grubunda olan kişilerin diğer yaş grubundan olan kişilere göre KSS'nin ekonomik boyutunu daha olumlu buldukları tespit edilmiştir (Smirnova, 2012). Bununla birlikte KSS algısının yaş gruplarına göre değişmediğini ortaya koyan çalışmalar da söz konusudur (Çelik, 2013: 145; Dickson, 2001; Çalışkan ve Ünüsan, 2011: 164). Otel çalışanları üzerinde yapılan bir araştırma sonucunda ise 35-39 yaș aralı̆̆ında olan çalıșanların çevreye karşı sosyal sorumluluk algıları en yüksek; 25-29 yaș aralığında olanların ise çevreye karșı sosyal sorumlulukları en düșük olan kișiler olduğu belirlenmiştir (Pelit, Keleş ve Çakır, 2009: 29). KSS'nin marka algısına etkisinin incelendiği araştırmanın sonucunda da, 16-25 yaş arası katılımcıların, KSS faaliyetlerinin marka farkındalığını etkilediği konusunda daha duyarlı oldukları belirlenmiş̧tir (Akkoyunlu ve Kalyoncuoğlu, 2014: 142).

Literatürdeki ilgili bulgulara dayanarak KSS'ye yönelik çalışan algılarının yaşa göre değişeceğine ilişkin araştırma hipotezi şu şekilde kurulmuştur:

\section{$H_{5}$ : Yaşa göre çalışanların kurumsal sosyal sorumluluk algılamaları farklılık göstermektedir.}

Toplam çalışma süresi değişkeni açısından KSS'ye yönelik algıda farklılık olup olmadığı incelendiğinde; bir araştırmada toplam çalışma süresi 10 yıldan fazla olan çalışanların, KSS'nin etik 
boyutunu daha olumlu buldukları belirlenmiştir (Kelley, Ferrell ve Skinner, 1990: 681). Bununla birlikte, toplam çalışma süresi açısından KSS'ye yönelik algılar arasında farklılık olmadı̆̆ 1 sonucuna ulaşan çalışmalar da söz konusudur (Çelik, 2013: 149; Yam ve Fredericks, 2009: 25). Bir çalışma sonucunda ise toplam çalışma süresi 21 ve üzeri olan çalışanların KSS'nin ekonomik boyutunu daha olumlu buldukları ve çalışma süresi arttıkça ekonomik boyuta yönelik algılarının daha olumlu olduğu belirlenmiştir (Smirnova, 2012). Otelcilik sektöründe yapılan bir başka araştırma sonucuna göre ise, katılımcıların çalışma süresi arttıkça, etik, yasal ve ekonomik KSS'ye yönelik algılarının arttı̆ğ belirlenmiştir (Çalışkan ve Ünüsan, 2011: 164).

Literatürdeki bu bulgulara dayanarak KSS'ye yönelik çalışan algılarının toplam çalışma süresine göre değişeceğine ilişkin araştırma hipotezi şu şekilde kurulmuştur:

\section{Ho: Toplam çalışma süresine göre çalışanların kurumsal sosyal sorumluluk algılamaları farklılık göstermektedir.}

Yukarıda belirtilen hipotezler ve bunlara bağlı olarak geliştirilen alt hipotezler doğrultusunda, çalışanların örgütlerinin KSS'ye ve KSS'nin alt boyutlarına ilişkin algılarının demografik özelliklerine göre değişip değişmediği, bu araştırma kapsamında belirlenmeye çalışılmıştır. Çalışmanın bundan sonraki kısmında, yapılan araştırmanın yöntemi ve sonuçları üzerinde durulacaktır.

\section{YÖNTEM}

Çalışmanın bu kısmında, öncelikle araştırmanın anakütlesi ve örneklemi, veri toplama aracı ve verilerin analizine yönelik bilgilere yer verilmiştir. Sonrasında ise araştırmaya katılan çalışanların özellikleri incelenmiş ve çalışanların KSS algılarının demografik özellikler açısından farklılık gösterip göstermediğinin belirlenmesi amacıyla, daha önce belirlenen hipotezler doğrultusunda yapılan analiz sonuçları ortaya konulmuştur.

\subsection{Araştırmanın Anakütlesi ve Örneklemi}

Araştırmanın anakütlesini, İstanbul ilinde, özel ve kamu kesiminde çalışan ve bankacılık, finans, eğitim vb. hizmet sektöründe faaliyet gösteren kişiler oluşturmaktadır. Araştırma kapsamının geniş tutulması amacıyla herhangi bir sektör vb. kısıtlamasına gidilmemiştir. Araştırmada örnekleme tekniği olarak kolayda örnekleme yöntemi tercih edilmiştir. Buna göre araştırmanın örneklem grubuna, yakın çevrede bulunan ve ulaşılması kolay, elde mevcut ve araştırmaya katılmak isteyen gönüllü bireyler dâhil edilmiştir. Araştırma kapsamında ilgili sektörlerde faaliyet gösteren yaklaşık 500 kişiye, elektronik ortamda oluşturulan ve basılı haldeki anket formları dağıtılmış ve anket formlarının 263'ü yanıtlanarak geri gönderilmiştir. 22 adet anket formu eksik olduğu için araştırma kapsamından çıkarılmış, kalan 241 anket formu araştırmaya dâhil edilmiştir Sonuç itibariyle araştırma 241 kişi kapsamında gerçekleştirilmiştir.

\subsection{Veri Toplama Aracı}


Araştırmada veri toplama aracı olarak anket yöntemi kullanılmıştır. Anket formunda çalışanların KSS'ye yönelik algılarını ölçebilmek için daha önce Maignan ve Ferrell ile Türker tarafından da kullanılan ölçekler esas alınarak Özdemir (2007) tarafından geliştirilen ve Demir ve Türkmen (2012) tarafından geçerlilik analizi yapılan 22 ifadeli bir ölçek kullanılmıştır. Bu ölçek KSS ile ilgili algıyı 22 ifade ve ekonomik, yasal, etik ve gönüllü sorumluluk olmak üzere dört boyut ile ölçmektedir. Ekonomik sorumluluk boyutu altı, yasal sorumluluk boyutu dört, etik sorumluluk boyutu yedi ve gönüllü sorumluluk boyutu beş ifadeden oluşmaktadır. "Kurumum çalışanlarının verimli çalışmasını sağlamaktadır", "Kurumum çalışanlarla ilgili kanuni düzenlemelere uygun hareket etmektedir", "Kurumum ürün ve hizmetleri hakkında müşterilere tam ve doğru bilgi sunmaktadır" ve "Kurumum çalışanlarının gönüllü olarak katıldıkları faaliyetleri desteklemektedir” ifadeleri, ölçekte yer alanlara örnek olarak verilebilir. Belirtilen bu ölçekteki ifadelere örneklemin demografik niteliklerine ait sorular da ilave edilerek anket formu tamamlanmıştır.

\subsection{Veri Analizi}

Veri toplama aracığının özelliği olduğundan, anket formunda yer verilen ölçekte, deneklerin örgütlerinin KSS'ye yönelik algıları, sınırları "1: Kesinlikle katılmıyorum”, “5: Kesinlikle katılıyorum" şeklinde ifade edilen 5'li bir Likert ölçeği ile belirlenmiştir. Veriler, SPSS Statistics 17.0 paket programında analiz edilmiştir. Öncelikle veri analizinde kullanılacak testleri belirlemek için Kolmogorov-Smirnov testi yapılmıştır. Bu test sonucunda verilerin normal dağıldığ 1 ve parametrik testlerin kullanılmasının gerekli olduğu belirlenmiştir. Çalışanların örgütlerinin kurumsal sosyal sorumluluğuna ilişkin algıların demografik değişkenlere göre farklılık gösterip göstermediğinin incelenmesi için t-testi ve tek yönlü varyans analizi (One-Way Anova) kullanılmıştır.

Verilerin güvenilirliği için Cronbach alpha güvenilirlik değeri hesaplanmıştır. KSS'ye yönelik algının belirlenmesinde kullanılan ve faktör analizi sonucunda 15 ifadeye düşürülen ölçeğe ait güvenilirlik değeri Cronbach $\alpha$ : 0,905 olarak bulunmuştur. Ölçeğin alt boyutlarının güvenilirlik değerleri de; ekonomik sorumluluk 0,736 , yasal sorumluluk 0,861 , etik sorumluluk 0,826 ve gönüllü sorumluluk 0,890 şeklindedir. Ölçeğe ait Cronbach alpha değerlerinin sosyal bilimlerde gerçekleştirilen araştırmalar açısından yüksek derecede güvenilir olduğu söylenebilir. Araştırmada kullanılan KSS ölçeğinin geçerliliği belirlemek için Keşifsel Faktör Analizi uygulanmıştır. Yapılan faktör analizinde Varimax Rotasyonu kullanılmış ve faktör yükleri için alt kesim noktası 0.45 olarak kabul edilmiştir. Faktör analizi sonucunda KMO değeri 0,846 olarak bulunmuştur. KSS'ye yönelik algının belirlenmesinde kullanılan ölçek için, faktör yükleri bu alt kesim noktasının altında olan; ekonomik sorumluluk için bir ifade, etik sorumluluk için beş ifade ve gönüllü sorumluluk için bir ifade ölçekten çıkarılmıştır. Ölçeğin boyutlarına ilişkin ifadelerin faktör yüklerine ait aralık değerleri; ekonomik sorumluluk $(0,518-0,866)$, yasal sorumluluk $(0,518-0,820)$, etik sorumluluk $(0,769-0,882)$ ve gönüllü sorumluluk $(0,538-0,922)$ olarak hesaplanmıştır. Elde edilen dört faktörün toplam varyans1 
açıklama oranı 0,731 tür. Birinci faktör, değişkenliğin \%44,5'ini, ikinci faktör \%11,17'sini, üçüncü faktör \%9,95'ini ve dördüncü faktör \% 7,49'unu açıklamaktadır.

\subsection{Bulgular ve Yorumlar}

Çalışmanın bu kısmında, öncelikle araştırmaya katılan çalışanların özellikleri incelenmiş, sonrasında ise çalışanların KSS algılarının demografik özellikler açısından farklılık gösterip göstermediğinin belirlenmesi amacıyla yapılan analiz sonuçları ortaya konulmuştur.

\subsubsection{Katılımcıların Özellikleri}

Araştırmaya katılan 241 çalışanın demografik özelliklerine ait genel bilgiler Tablo 1 üzerinde görülebilir.

Tablo 1. Araştırma Katılımcılarının Demografik Özellikleri

\begin{tabular}{|c|c|c|c|c|c|c|c|}
\hline \multicolumn{2}{|c|}{ Değişken adı } & \multirow{2}{*}{\begin{tabular}{|c|}
$\begin{array}{c}\text { Toplam } \\
\text { Frekans }\end{array}$ \\
67 \\
174
\end{tabular}} & \multirow{2}{*}{$\begin{array}{l}\boldsymbol{( \% )} \\
27,8 \\
72,2 \\
\end{array}$} & \multicolumn{2}{|c|}{ Değişken Adı } & \multirow{2}{*}{\begin{tabular}{|c|}
$\begin{array}{c}\text { Toplam } \\
\text { Frekans }\end{array}$ \\
125 \\
116
\end{tabular}} & \multirow{2}{*}{$\begin{array}{l}(\%) \\
51,8 \\
48,2\end{array}$} \\
\hline Cinsiyet & $\begin{array}{l}\text { Kadın } \\
\text { Erkek }\end{array}$ & & & Medeni Hal & $\begin{array}{l}\text { Evli } \\
\text { Bekar }\end{array}$ & & \\
\hline Eğitim & $\begin{array}{l}\text { Lisans } \\
\text { Lisansüstü }\end{array}$ & $\begin{array}{c}161 \\
80\end{array}$ & $\begin{array}{l}66,8 \\
33,2 \\
\end{array}$ & $\begin{array}{l}\text { Çalışılan } \\
\text { Sektör }\end{array}$ & $\begin{array}{l}\text { Kamu } \\
\text { Özel }\end{array}$ & $\begin{array}{c}63 \\
178 \\
\end{array}$ & $\begin{array}{l}26,1 \\
73,9\end{array}$ \\
\hline $\begin{array}{c}\text { Yaş } \\
\text { grupları }\end{array}$ & $\begin{array}{l}15-25 \\
26-30 \\
31-35 \\
36 \text { ve üzeri }\end{array}$ & $\begin{array}{c}51 \\
100 \\
39 \\
51\end{array}$ & $\begin{array}{l}21,2 \\
41,4 \\
16,2 \\
21,2\end{array}$ & $\begin{array}{l}\text { Toplam } \\
\text { Çalışılan } \\
\text { Süre }\end{array}$ & $\begin{array}{l}1 \text { yıldan az } \\
1-5 \text { y1l arası } \\
5-10 \text { yıl arası } \\
10-15 \text { y1l aras1 } \\
15 \text { y1l ve üzeri }\end{array}$ & $\begin{array}{l}22 \\
97 \\
56 \\
24 \\
42 \\
\end{array}$ & $\begin{array}{l}9,12 \\
40,2 \\
23,2 \\
9,96 \\
17,4 \\
\end{array}$ \\
\hline
\end{tabular}

Tablo incelendiğinde; araştırmaya katılan toplam 241 kişinin ağırlıklı olarak erkek olduğu ve yaklaşık yarısının bekâr ve yarısının evli olduğu görülmektedir. Bunun yanında katılımcıların yaklaşık \%67'sinin lisans, \%33'ünün ise lisansüstü düzeyde mezun olduğu tespit edilmiştir. Katıllmcılar ağırlıklı olarak özel sektörde çalışmaktadır. Katılımcıların \%21'i 15-25; \%41'i ise 26-30 yaş grubunda bulunmaktadır. Dolayısıyla katılımcılar içerisinde ağırlık olarak 15-30 yaş arasında olan bireylerin olduğu söylenebilir. Son olarak toplam çalışma süreleri açısından bakıldığında özellikle 1-5 yıl arası ve 5-10 yıl arası kıdemi olan çalışanların sayıca daha fazla olduğu görülmektedir.

\subsubsection{Demografik Özellikler Açısından Çalışanların Kurumsal Sosyal Sorumluluk} Algılarına Yönelik Farklılıklar

Araştırmada KSS'ye ve KSS'nin alt boyutlarına yönelik algının demografik bazı değişkenlere göre farklılık gösterip göstermediği, oluşturulan hipotezler doğrultusunda aşağıda incelenmiştir.

$H_{1}$ : Çalışanların cinsiyetine göre kurumsal sosyal sorumluluk algılamaları farklılık göstermektedir.

$H_{1 a}$ : Çalısanların cinsiyetine göre KSS'nin ekonomik sorumluluk boyutuna yönelik algılamaları farklılık göstermektedir. 
$H_{l b}$ : Çalışanların cinsiyetine göre KSS'nin yasal sorumluluk boyutuna yönelik algılamaları farklılık göstermektedir.

$H_{1 c}$ : Çalışanların cinsiyetine göre KSS'nin etik sorumluluk boyutuna yönelik algilamaları farklılı göstermektedir.

$H_{1 d}$ : Çalışanların cinsiyetine göre KSS'nin gönüllü sorumluluk boyutuna yönelik algılamaları farklılık göstermektedir.

Cinsiyet değişkenine göre katılımcıların KSS'ye ve KSS'nin alt boyutlarına yönelik algılarının farklılaşıp farklılaşmadığının tespiti için yapılan t testi sonuçları Tablo 2'de görülebilir.

Tablo 2. Cinsiyete Göre Kurumsal Sosyal Sorumluluğa Yönelik Tanımlayıcı İstatistikler ve Farklılıklar

\begin{tabular}{|c|c|c|c|}
\hline & Erkek Ort. & Kadın Ort. & Anlamlılık Değeri \\
\hline Kurumsal Sosyal Sorumluluk (Genel) & 3,67 & 3,47 & $0,011<0,05 *$ \\
\hline a. Ekonomik Sorumluluk & 3,46 & 3,55 & $0,333>0,05 *$ \\
\hline b. Yasal Sorumluluk & 4,19 & 3,90 & $0,004<0,05$ \\
\hline c. Etik Sorumluluk & 3,69 & 3,54 & $0,257>0,05$ \\
\hline d. Gönüllü Sorumluluk & 3,33 & 2,90 & $0,002<0,05$ \\
\hline
\end{tabular}

* Varyansların eşit olmadığı durum

Tablo incelendiğinde cinsiyet değişkenine göre katılımcıların genel KSS algılarının 0,05 anlamlılık düzeyinde anlamlı olarak farklılaştığı belirlenmiş ve $\underline{\mathbf{H}}_{1}$ hipotezi kabul edilmiștir. Ortalamalara bakıldığında erkeklerin kadınlara göre örgütlerine yönelik genel KSS algılarının daha yüksek olduğu görülmektedir. KSS'nin alt boyutları itibariyle bakıldığında ise; yasal sorumluluğa ve gönüllü sorumluluğa yönelik algıların cinsiyet değişkenine göre istatistiksel olarak anlamlı şekilde

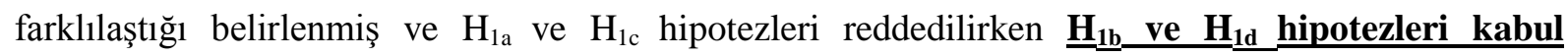
edilmiștir. Sonuçlar incelendiğinde her iki boyutta da, erkeklerin kadınlara göre, örgütlerine ilişkin KSS algılarının daha yüksek olduğu belirlenmiştir.

$\mathrm{H}_{2}$ : Medeni duruma göre, çalışanların kurumsal sosyal sorumluluk algılamaları farklılık göstermektedir.

$H_{2 a}:$ Medeni durumuna göre, çalışanların KSS'nin ekonomik sorumluluk boyutuna yönelik algılamaları farklılık göstermektedir.

$H_{2 b}$ : Medeni durumuna göre, çalışanların KSS'nin yasal sorumluluk boyutuna yönelik algılamaları farklılı göstermektedir.

$H_{2 c}:$ Medeni durumuna göre, çalışanların KSS'nin etik sorumluluk boyutuna yönelik algılamaları farklılık göstermektedir.

$H_{2 d}:$ Medeni durumuna göre, çalışanların KSS'nin gönüllü sorumluluk boyutuna yönelik algılamaları farklılık göstermektedir. 
Medeni durum değişkenine göre katılımcıların KSS'ye ve KSS'nin alt boyutlarına yönelik algılarının farklılaşıp farklılaşmadığının tespiti için yapılan t testi sonuçları Tablo 3'de görülebilir.

Tablo 3. Medeni Duruma Göre Kurumsal Sosyal Sorumluluğa Yönelik Tanımlayıcı İstatistikler ve Farklılıklar

\begin{tabular}{|l|c|c|c|}
\hline & Evli Ort. & Bekâr Ort. & Anlamlılık Değeri \\
\hline Kurumsal Sosyal Sorumluluk (Genel) & 3,67 & 3,56 & $0,200>0,05^{*}$ \\
\hline a. Ekonomik Sorumluluk & 3,56 & 3,40 & $0,093>0,05$ \\
\hline b. Yasal Sorumluluk & 4,20 & 4,02 & $\mathbf{0 , 0 3 8}<\mathbf{0 , 0 5}$ \\
\hline c. Etik Sorumluluk & 3,63 & 3,67 & $0,767>0,05^{*}$ \\
\hline d. Gönüllü Sorumluluk & 3,27 & 3,14 & $0,312>0,05$ \\
\hline
\end{tabular}

* Varyansların eşit olmadığı durum

Tablo incelendiğinde, medeni durum değişkenine göre katılımcıların genel KSS algılarının 0,05 anlamlılık düzeyinde anlamlı olarak farklılaşmadığ 1 belirlenmiş ve $\mathrm{H}_{2}$ hipotezi reddedilmiştir. Ortalamalara bakıldığında evli katılımcıların bekâr katılımcılara göre örgütlerine yönelik genel KSS algılarının daha yüksek olduğu ancak aradaki farklılığın istatistiksel olarak anlamlı olmadığı söylenebilir. Bununla birlikte KSS'nin alt boyutları itibariyle bakıldığında; sadece yasal sorumluluk boyutuna yönelik algının medeni durum değişkenine göre 0,05 anlamlılık düzeyinde anlamlı olarak farklılaştığ 1 belirlenmiş ve $\mathrm{H}_{2 \mathrm{a}}$ ve $\mathrm{H}_{2 \mathrm{c}}$ ve $\mathrm{H}_{2 \mathrm{~d}}$ hipotezleri reddedilirken $\underline{\mathbf{H}}_{2 \mathbf{b}}$ hipotezi kabul edilmiștir. Ortalamalar incelendiğinde evli katılımcıların bekâr katılımcılara göre örgütlerine yönelik yasal sorumluluk boyutuna ilişkin algılarının daha yüksek olduğu belirlenmiştir.

$H_{3}$ : Ĕ̆itim düzeyine göre çalışanların kurumsal sosyal sorumluluk algılamaları farklılık göstermektedir.

$H_{3 a}$ : Eğitim düzeyine göre, çalışanların KSS'nin ekonomik sorumluluk boyutuna yönelik algılamaları farklılı göstermektedir.

$H_{3 b}:$ Eğitim düzeyine göre, çalışanların KSS'nin yasal sorumluluk boyutuna yönelik algılamaları farklılık göstermektedir.

$H_{3 c}$ : Ĕ̆itim düzeyine göre, çalışanların KSS'nin etik sorumluluk boyutuna yönelik algılamaları farklılık göstermektedir.

$H_{3 d}$ : Eğitim düzeyine göre, çalışanların KSS'nin gönüllü sorumluluk boyutuna yönelik algılamaları farklılı göstermektedir.

Eğitim düzeyi değişkenine göre katılımcıların KSS'ye ve KSS'nin alt boyutlarına yönelik algılarının farklılaşıp farklılaşmadığının tespiti için yapılan t testi sonuçları Tablo 4'te görülebilir. 
Tablo 4. Eğitim Düzeyine Göre Kurumsal Sosyal Sorumluluğa Yönelik Tanımlayıcı İstatistikler ve Farklılıklar

\begin{tabular}{|c|c|c|c|}
\hline & Lisans Ort. & Lisansüstü Ort. & Anlamlılık Değeri \\
\hline Kurumsal Sosyal Sorumluluk (Genel) & 3,68 & 3,49 & $0,044<0,05$ \\
\hline a. Ekonomik Sorumluluk & 3,59 & 3,27 & $0,003<0,05 *$ \\
\hline b. Yasal Sorumluluk & 4,12 & 4,08 & $0,605>0,05$ \\
\hline c. Etik Sorumluluk & 3,75 & 3,45 & $0,035<0,05 *$ \\
\hline d. Gönüllü Sorumluluk & 3,23 & 3,16 & $0,603>0,05$ \\
\hline
\end{tabular}

* Varyansların eşit olmadığı durum

Tablo incelendiğinde, eğitim düzeyi değişkenine göre katılımcıların genel KSS algılarının 0,05 anlamlılık düzeyinde anlamlı olarak farklılaştığı belirlenmiş ve $\underline{\mathbf{H}}_{3}$ hipotezi kabul edilmiștir. Ortalamalara bakıldığında lisans mezunu katılımcıların lisansüstü mezuniyet derecesine sahip katılımcılara göre örgütlerine yönelik KSS algılarının daha yüksek olduğu görülmektedir. KSS'nin alt boyutları itibariyle bakıldığında ise; ekonomik sorumluluğa ve etik sorumluluğa yönelik algıların eğitim düzeyi değişkenine göre istatistiksel olarak anlamlı şekilde farklılaştığı belirlenmiş ve $\mathrm{H}_{3 \mathrm{~b}}$ ve

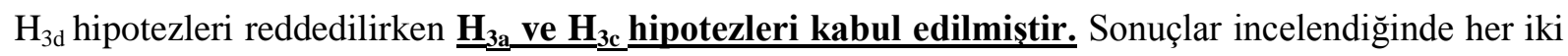
boyuta yönelik, lisans mezunu katılımcıların lisansüstü mezuniyet derecesine sahip katılımcılara göre örgütlerine yönelik kurumsal sosyal sorumluluk algılarının daha yüksek olduğu belirlenmiştir.

$H_{4}:$ Çalışılan sektöre göre çalışanların kurumsal sosyal sorumluluk algılamaları farklılık göstermektedir.

$H_{4 a}$ : Çalışılan sektöre göre, çalışanların KSS'nin ekonomik sorumluluk boyutuna yönelik algılamaları farklılık göstermektedir.

$H_{4 b}$ : Çalışılan sektöre göre, çalışanların KSS'nin yasal sorumluluk boyutuna yönelik algılamaları farklılı göstermektedir.

$H_{4 c}$ : Çalışılan sektöre göre, çalışanların KSS'nin etik sorumluluk boyutuna yönelik algılamaları farklılı göstermektedir.

$H_{4 d}$ : Çalışılan sektöre göre, çalışanların KSS'nin gönüllü sorumluluk boyutuna yönelik algılamaları farklılı göstermektedir.

Çalışılan sektör değişkenine göre katılımcıların KSS'ye ve KSS'nin alt boyutlarına yönelik algılarının farklılaşıp farklılaşmadığının tespiti için yapılan t testi sonuçları Tablo 5'de görülebilir.

Tablo 5. Çalışılan Sektöre Göre Kurumsal Sosyal Sorumluluğa Yönelik Tanımlayıcı İstatistikler ve Farklılıklar

\begin{tabular}{|c|c|c|c|}
\hline & Kamu Ort. & Özel Ort. & Anlamlılık Değeri \\
\hline Kurumsal Sosyal Sorumluluk (Genel) & 3,29 & 3,73 & $0,000<0,05$ \\
\hline a. Ekonomik Sorumluluk & 3,05 & 3,64 & $0,000<0,05$ \\
\hline b. Yasal Sorumluluk & 4,07 & 4,13 & $0,541>0,05$ \\
\hline c. Etik Sorumluluk & 2,94 & 3,90 & $0,000<0,05 *$ \\
\hline d. Gönüllü Sorumluluk & 3,10 & 3,25 & $0,309>0,05$ \\
\hline
\end{tabular}

* Varyansların eşit olmadığı durum 
Tablo incelendiğinde, çalışılan sektör değişkenine göre katılımcıların genel KSS algılarının 0,05 anlamlılık düzeyinde anlamlı olarak farklılaştığı belirlenmiş ve $\underline{\mathbf{H}}_{4}$ hipotezi kabul edilmiștir. Ortalamalara bakıldığında özel sektörden katılanların kamu sektöründen katılanlara göre örgütlerine yönelik KSS algılarının daha yüksek olduğu görülmektedir. KSS'nin alt boyutları itibariyle bakıldığında ise; ekonomik sorumluluğa ve etik sorumluluğa yönelik algıların çalışılan sektör değişkenine göre istatistiksel olarak anlamlı şekilde farklılaştığı belirlenmiş ve $\mathrm{H}_{4 \mathrm{~b}}$ ve $\mathrm{H}_{4 \mathrm{~d}}$ hipotezleri

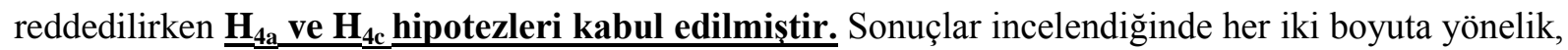
özel sektörden katılanların kamu sektöründen katılanlara göre örgütlerine yönelik KSS algılarının daha yüksek olduğu belirlenmiştir.

$H_{5}:$ Yaşa göre çalışanların kurumsal sosyal sorumluluk algılamaları farklılık göstermektedir.

$H_{5 a}$ : Yaşa göre, çalışanların KSS'nin ekonomik sorumluluk boyutuna yönelik algılamaları farklılık göstermektedir.

$H_{5 b}$ : Yaşa göre, çalışanların KSS'nin yasal sorumluluk boyutuna yönelik algılamaları farklılı göstermektedir.

$H_{5 c}$ : Yaşa göre, çalışanların KSS'nin etik sorumluluk boyutuna yönelik algılamaları farklılık göstermektedir.

$H_{5 d}$ : Yaşa göre, çalışanların KSS'nin gönüllü sorumluluk boyutuna yönelik algılamaları farklılı göstermektedir.

Yaş değişkenine göre katılımcıların KSS'ye ve KSS'nin alt boyutlarına yönelik algılarının farklılaşıp farklılaşmadığının tespiti için Tek yönlü Varyans Analizi (One-way ANOVA testi) yapılmıştır. Varyans Analizi için öncelikle Levene testinin sonuçları değerlendirilmiş ve Varyans Analizi'nin temel varsayımı olan varyansların homojenliğinin sağlanıp sağlanmadığına bakılmıştır. Levene testi sonuçları incelendiğinde KSS ve KSS'nin ekonomik, yasal ve etik sorumluluk boyutları için varyansların homojen olmadığı belirlenmiştir. Bu nedenle Varyans Analizi’nin sonuçlarına sadece gönüllü sorumluluk boyutu için bakılmıştır. Gönüllü sorumluluk boyutu için de KSS algılarının yaş gruplarına göre 0,05 anlamlı1ık düzeyinde anlamlı olarak farklılaştığı belirlenmiş ve $\mathrm{H}_{5}, \mathrm{H}_{5 \mathrm{a}}, \mathrm{H}_{5 \mathrm{~b} \text { ve }} \mathrm{H}_{5 \mathrm{c}}$

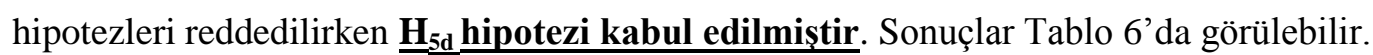

Tablo 6. Yaşa Göre Kurumsal Sosyal Sorumluluğa Yönelik Tanımlayıcı İstatistikler ve Farklılıklar

\begin{tabular}{|l|c|c|c|c|c|}
\hline & $\mathbf{1 5 - 2 5}$ arası & $\mathbf{2 6 - 3 0}$ arası & $\mathbf{3 1 - 3 5}$ arası & $\mathbf{3 6}$ ve üstü & Anlamlılı Değgeri \\
\hline d. Gönüllü Sorumluluk & 3,44 & 2,98 & 3,60 & 3,13 & $\mathbf{0 , 0 0 3 < 0 , 0 5}$ \\
\hline
\end{tabular}

Gönüllü sorumluluğa yönelik algılara ilişkin farklılığın hangi gruplar arasında olduğunu belirlemek için Post-Hoc (Tukey) testinden yararlanılmıştır. Sonuçlar incelendiğinde, yaş1 26-30 aralığında olanlar ile 15-25 aralığında olanlar arasında $(\mathrm{p}=0,037<0,05)$ ve yine yaşı 26-30 aralığında olanlar ile 31-35 aralığında olanlar arasında $(\mathrm{p}=0,005<0,05)$ anlamlı farklılık olduğu belirlenmiştir. 
Ortalamalara bakıldığında yaşı 26-30 arasında olan katılımcıların, yaşı 15-25 arasında olan katılımcılara ve yaşı 31-35 arasında olan katılımcılara göre gönüllü sorumluluk boyutuna yönelik algılarının daha olumsuz olduğu görülmektedir.

H.: Toplam çalışma süresine göre çalışanların kurumsal sosyal sorumluluk algılamaları farklılık göstermektedir.

$H_{6 a}:$ Toplam çalışma süresine göre, çalışanların KSS'nin ekonomik sorumluluk boyutuna yönelik algılamaları farklılı göstermektedir.

$H_{6 b}:$ Toplam çalışma süresine göre, çalışanların KSS'nin yasal sorumluluk boyutuna yönelik algılamaları farklılı göstermektedir.

$H_{6 c}$ : Toplam çalışma süresine göre, çalışanların KSS'nin etik sorumluluk boyutuna yönelik algılamaları farklılık göstermektedir.

$H_{6 d}$ : Toplam çalışma süresine göre, çalışanların KSS'nin gönüllü̈ sorumluluk boyutuna yönelik algllamaları farklılı göstermektedir.

Toplam çalışma süresi değişkenine göre katılımcıların KSS'ye ve KSS'nin alt boyutlarına yönelik algılarının farklılaşıp farklılaşmadığının tespiti için Tek yönlü Varyans Analizi (One-way ANOVA testi) yapılmıştır. Varyans Analizi için öncelikle Levene testinin sonuçları değerlendirilmiş ve Varyans Analizi'nin temel varsayımı olan varyansların homojenliğinin sağlanıp sağlanmadığına bakılmıştır. Levene testi sonuçları incelendiğinde KSS ve KSS'nin ekonomik ve gönüllü sorumluluk boyutları için varyansların homojen olmadığı belirlenmiş ve Varyans Analizi'nin sonuçlarına sadece yasal ve etik sorumluluk boyutları için bakılmıştır. Her iki boyut için de KSS algılarının toplam çalışma süresi gruplarına göre 0,05 anlamlılık düzeyinde anlamlı olarak farklılaştı̆̆ belirlenmiş ve $\mathrm{H}_{6}$,

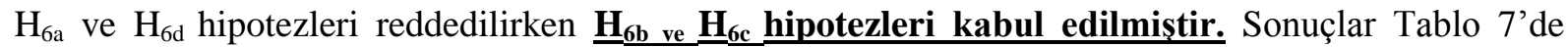
görülebilir.

Tablo 7. Toplam Çalışma Süresine Göre Kurumsal Sosyal Sorumluluğa Yönelik Tanımlayıcı İstatistikler ve Farklılıklar

\begin{tabular}{|l|c|c|c|c|c|c|}
\hline & $\mathbf{1}$ yıldan az & $\mathbf{1 - 5}$ yll & $\mathbf{5 - 1 0}$ yıl & $\mathbf{1 0 - 1 5}$ yıl & $\mathbf{1 5}$ yıl ve üst. & Anlamlılık Değeri \\
\hline b. Yasal Sorumluluk. & 4,39 & 4,08 & 3,97 & 3,81 & 4,34 & $\mathbf{0 , 0 0 5}<\mathbf{0 , 0 5}$ \\
\hline c. Etik Sorumululuk & 3,81 & 3,58 & 3,82 & 3,13 & 3,74 & $\mathbf{0 , 0 2 8}<\mathbf{0 , 0 5}$ \\
\hline
\end{tabular}

Yasal ve etik sorumluluğa yönelik algılara ilişkin farklılığın hangi gruplar arasında olduğunu belirlemek için Post-Hoc (Tukey) testinden yararlanılmıştır. Yasal sorumluluğa yönelik sonuçlar incelendiğinde, 1 yıldan az çalışanlar ile $10-15$ y1l aralığında çalışanlar arasında $(p=0,035<0,05)$ ve 10 15 y1l aralığında çalışanlar ile 15 y1l ve üstü çalışanlar arasında $(\mathrm{p}=0,024<0,05)$ anlamlı farklılık olduğu belirlenmiştir. Ortalamalara bakıldığında 1 yıldan az çalışanların ve 15 yıl ve üstü çalışanların, 10-15 yıl arasında çalışanlara göre yasal sorumluluk boyutuna yönelik algılarının daha olumlu olduğu görülmektedir. Etik sorumluluğa yönelik sonuçlar incelendiğinde ise, 5-10 yıl aralığında çalışanlar ile 
10-15 yıl aralığında çalışanlar arasında $(\mathrm{p}=0,022<0,05)$ anlamlı farklılık olduğu belirlenmiştir. Ortalamalara bakıldığında 5-10 yıl arasında çalışanların, 10-15 yıl arasında çalışanlara göre etik sorumluluk boyutuna yönelik algılarının daha olumlu olduğu görülmektedir.

\section{SONUÇ}

Kurumsal sosyal sorumluluk, genel olarak örgütlerin ilişkide bulunduğu tüm iç ve dış çevre faktörlerine karşı sorumlu davranmasını ifade eden bir kavram olarak tanımlanabilir. Önceleri örgütün verimli çalışması, kaliteli ürün ve hizmet sunması, kanuni yükümlülükleri yerine getirmesi gibi ekonomik ve yasal boyutlar çerçevesinde incelenen KSS, son yıllarda çalışanların yaşam kalitesini artırma, müşteri memnuniyetine önem verme, hayırsever kuruluşlara yardımda bulunma, eğitim, sağlık, kültür ve sanat gibi faaliyetlere destek olma gibi, özellikle etik ve gönüllü sorumluluklar bağlamında değerlendirilmektedir.

Yapılan araştırmada çalışanların KSS'ye ve KSS'nin alt boyutlarına yönelik algılarının bazı demografik değişkenlere göre farklılık gösterip göstermediğinin belirlenmesi amaçlanmıştır. Elde edilen sonuçlar incelendiğinde; erkeklerin kadınlara göre örgütlerine ilişkin genel KSS algılarının; alt boyutlar itibariyle ise yasal ve gönüllü sorumlulukların yerine getirilmesine yönelik algılarının daha olumlu olduğu görülmektedir. Cinsiyet açısından gönüllü sorumluluk boyutuna ilişkin bu farklılığın, kadın katılımcıların özellikle gönüllü uygulama ve faaliyetlere ilişkin beklentilerinin daha fazla olması ve mevcut uygulamaları yeterli görmemelerinden kaynaklandığı düşünülebilir. Ayrıca yasal sorumluluk boyutu için ortaya çıkan farklılı̆̆ın, toplum genelinde kadınların gerek iş bulma, gerek istihdam edilme ve gerekse de işten çıkarılma konusunda haksızlığa uğradıklarına yönelik genel kanaati doğrular nitelikte olduğu söylenebilir.

Medeni durum açısından bakıldığında evli katılımcıların bekâr katılımcılara göre örgütlerinin yasal sorumluluklarına yönelik algılarının daha olumlu olduğu belirlenmiştir. Dolayısıyla sorumlulukları daha fazla olan evli çalışanların, işten ayrılma niyetlerinin de daha düşük olabileceği düşüncesiyle, örgütlerinin kanunlara uygun bir şekilde faaliyetlerini sürdürdüklerine daha çok inandıkları düşünülebilir.

Eğitim düzeyi bakımından farkl1lıklar incelendiğinde ise, lisans mezunu katılımc1ların lisansüstü mezuniyet derecesine sahip katılımcılara göre örgütlerine ilişkin genel KSS algılarının; alt boyutlar itibariyle ise ekonomik ve etik sorumlulukların yerine getirilmesine yönelik algılarının daha olumlu olduğu görülmektedir. Lisansüstü mezuniyet derecesine sahip çalışanların, gerek genel KSS algısı gerekse KSS'nin alt boyutlarına yönelik algısının göreceli olarak düşük olmasında, KSS'ye ilişkin beklentilerinin daha yüksek olmasının etkili olduğu söylenebilir. Keza eğitim düzeyi yükseldikçe, sosyal sorumluluğa ilişkin uygulama ve faaliyetlere yönelik duyarlıllı̆ın arttığ1 düşünülmektedir. 
Çalışılan sektör açısından sonuçlar incelendiğinde özel sektörde çalışan katılımcıların kamu sektöründe çalışan katılımcılara göre örgütlerine ilişkin genel KSS algılarının; alt boyutlar itibariyle ise ekonomik ve etik sorumlulukların yerine getirilmesine yönelik algılarının daha olumlu olduğu görülmektedir. Kamu sektöründe genel olarak verimli çalışma, müşteri/hizmet alan memnuniyeti sağlama, rakiplere göre rekabet avantajına sahip olma gibi ekonomik sorumluluğa ilişkin faaliyetlerin ve sosyal sorumluluk projelerinin pek önemsenmediği göz önünde bulundurulduğunda, söz konusu farklılığın anlamlı olduğu düşünülebilir.

Yaş grupları arasındaki farklılık incelendiğinde ise yaşı nispeten orta düzeyde olan katılımcıların daha genç ve daha yaşlı katılımcılara göre, örgütlerinin gönüllü sorumluluğuna yönelik algılarının daha olumsuz olduğu görülmektedir. Buna göre özellikle orta yaş grubunda yer alan katılımcıların, gönüllü sorumluluğa yönelik beklentilerinin daha yüksek olduğu söylenebilir.

Toplam çalışma süresi açısından sonuçlar incelendiğinde ise, yasal sorumluluk boyutu açısından aynen yaş değişkeninde olduğu gibi çalışma süresi nispeten orta düzeyde olan katılımcıların, iş hayatına henüz yeni girmiş katılımcılara ve kıdemi çok daha fazla olan katılımcılara göre algılarının daha olumsuz olduğu görülmektedir. İlgili sonucun; iş hayatına yeni girmiş çalı̧̧anlar için, bir işe girebilmiş olmanın verdiği mutlulukla diğer hususların önemsenmemesinden; kıdemi çok daha fazla olan çalışanlar içinse iş hayatının şartlarına alışılmasından ve olabilecek bazı yasal ihlâllerin mazur görülmesinden kaynaklandığı düşünülebilir. Çalışma süresi nispeten orta düzeyde olan katılımcıların ise yasal konularda söz konusu olabilecek olumsuzluklara karşı daha hassas oldukları söylenebilir. Toplam çalışma süresine etik sorumluluk boyutu açısından bakıldığında ise çalışma süresi 5-10 yıl arasında olanların kıdemi 10-15 yıl arasında olanlara göre daha olumlu oldukları belirlenmiştir. Buna göre, toplam çalışma süresi 10-15 yıl arasında olan katılımcıların, örgütlerinin gönüllü sorumluluğa yönelik faaliyetleri konusunda daha kararsız oldukları, bu doğrultuda da gönüllü sorumluluklarla ilgili yapılanlardan daha fazlasını istedikleri düşünülebilir.

Elde edilen tüm sonuçlar doğrultusunda; işletmelerin özellikle kadınlara yönelik gönüllü sosyal sorumluluk uygulamalarına ve kadın çalışanları memnun edecek uygulama ve faaliyetlere önem vermeleri gerektiği düşünülmektedir. Buna göre işletmeler, kadın çalışanlarını da memnun edecek ve onların istihdama katılımını olumlu etkileyecek şekilde, çalışanlarının özel hayatlarını daha iyi hale getirecek uygulamalara ve eğitim, sağlık, kültür ve sanat gibi faaliyetlere ağırlık vermeli, toplumun sosyal sorunlarının çözümüne yönelik çaba göstermelidir. Bunun yanında çalışanların eğitim düzeyi ve çalıştıkları sektör açısından işletmelerinin ekonomik ve etik sorumluluklarına ilişkin algıları arasında önemli farklılıklar olması nedeniyle; işletmelerin özellikle eğitim düzeyi yüksek çalışanların KSS'nin etik boyutuna yönelik algılarını iyileştirecek şekilde, yaşam kalitesini artırıcı sosyal hakları sağlaması; sağlığı, güvenliği ve refahı koruyucu düzenlemeler getirmesi ve doğal çevreyi korumaya ve geliştirmeye dönük faaliyetlere aktif olarak katılması önemli görülmektedir. Benzer şekilde kamu sektöründe çalışanların KSS'nin ekonomik boyutuna yönelik algılarını olumlu etkileyecek şekilde, 
kamu sektöründe çalışanların verimli çalışmalarının sağlanması, kurumların özel sektörle rekabet edilebilir hale gelmesi ve müşterilere kaliteli ürün veya hizmet sunulması önemli görülmektedir. Yaş açısından bakıldığında, işletmelerin, KSS'nin gönüllülük boyutuna yönelik algının iyileştirilmesi konusunda özellikle orta yaş seviyesinde (26-30 yaş) olan çalışanlara odaklanmalarının uygun olacağ1 düşünülmektedir. Gerekirse bu yaş grubunda olan çalışanların gönüllü sosyal sorumluluğa ilişkin beklentileri öğrenilerek onların istekleri doğrultusunda hareket edilebilir. Toplam çalışma süresi açısından bakıldığında ise, işletmelerin, KSS'nin yasal ve etik boyutlarına yönelik algının iyileştirilmesi konusunda özellikle orta düzeyde çalışma süresine sahip (10-15 y1l) çalışanlara odaklanmalarının uygun olacağı düşünülmektedir. Keza araştırma sonuçlarından, kanunlara uygun bir şekilde faaliyetleri sürdürmenin, çalı̧̧anlarla ilgili kanuni düzenlemelere uygun hareket etmenin ve etik sorumluluklara yönelik beklentilerin karşılanmasının, orta düzeyde çalışma süresine sahip çalışanlar tarafından daha çok önemsendiği anlaşılmaktadır.

Son olarak belirtmek gerekirse, işletmelerin KSS'ye ve KSS'nin alt boyutlarına yönelik uygulama ve faaliyetlerinin çalışanlarca nasıl algılandığının belirlenmesini amaçlayan çalışmaların sayısının hızla artacağı ve konunun gündemdeki yerini uzun süre koruyacağı düşünülmektedir. Müteakip çalışmalarda, KSS ve KSS’nin alt boyutlarına yönelik algı ile işten ayrılma niyeti, örgütsel özdeşleşme, örgütsel güven, iş tatmini, örgütsel performans, iş performans1, örgütsel vatandaşlik davranışı vb. değişkenler arasındaki ilginin araştırılabileceği; KSS'nin alt boyutlarına yönelik algının söz konusu değişkenlere etkisinin olup olmadığının incelenebileceği düşünülmektedir.

\section{KAYNAKÇA}

Akbaş, E. (2010) "Kurumsal Sosyal Sorumluluk Uygulamalarının Tüketici Marka Bağl11ı̆̆na Etkisinin Araştırılması", Yüksek Lisans Tezi, Onsekiz Mart Üniversitesi, Sosyal Bilimler Enstitüsü, Çanakkale.

Akkoyunlu, G. Ş. ve Kalyoncuoğlu, S. (2014) "İşletmelerin Kurumsal Sosyal Sorumluluk Çalışmalarının Marka Algısı Üzerine Etkisinin Değerlendirilmesi”, Niğde Üniversitesi İktisadi ve İdari Bilimler Fakültesi Dergisi, 7(3): 125-144.

Aktan, C. C. ve Vural, İ. Y. (2007) "Çokuluslu Şirketler ve Sosyal Sorumluluk" Coşkun Can Aktan (eds.) Kurumsal Sosyal Sorumluluk, İstanbul, İGİAD Yayınları.

Andriof, J. (2002) "Unfolding Stakeholder Thinking: Theory, Responsibility and Engagement", United Kingdom, Greenleaf Publishing.

Bıçakçı, A. B. (2011) "Halkla İlişkilerde Kurumsal Sosyal Sorumluluk Algısının Ölçümü”, Global Media Journal, 1(2): 1-30. 
Boeger, N. (2008) "Perspectives on Corporate Social Responsibility”, United Kingdom, Edward Elgar Publishing.

Brammer, S., Millington, A. ve Rayton, B. (2007) "The Contribution of Corporate Social Responsibility to Organizational Commitment", International Journal of Human Resource Management, 18(10): 1701-1719.

Carroll, A. B. (1991) "The Pyramid of Corporate Social Responsibility: Toward the Moral Management of Organizational Stakeholders”, Business Horizons, 34(4): 39-48.

Chattananon, A., Lawley, M., Trimetsoontorn, J., Supparerkchaisakul, N. ve Leelayouthayothin, L. (2007) "Building Corporate Image through Societal Marketing Programs", Society and Business Review, 2(3): 230-253.

Çalışkan, O. ve Ünüsan, Ç. (2011) "Otel Çalışanlarının Kurumsal Sosyal Sorumluluk Algısının İş Tatmini ve İşte Kalma Niyetine Etkisi”, Anatolia: Turizm Araştırmaları Dergisi, 22(2): 154-166.

Çelik, Y. (2013) "Çalışanların İşletmenin Kurumsal Sosyal Sorumluluk Faaliyetlerine Yönelik Algısı ile İş Tatmini Arasındaki İlişki ve Bir Araştırma”, Yüksek Lisans Tezi, İstanbul Üniversitesi, Sosyal Bilimler Enstitüsü, İstanbul.

Crane, A., Matten, D., Mcwillams, A., Moon, J. ve Siegel, D. (2008) "The Oxford Handbook of Corporate Social Responsibility”, United Kingdom, Oxford Handbooks Online.

Davis, K. (1960) “Can Business Afford to Ignore Social Responsibilities?”, California Management Review, 2(3): 70-76.

Demir, R. ve Türkmen, E. (2012) "Çalışanların Kurumsal Sosyal Sorumluluk Algılamalarının Örgüte Bağl11ıkları Üzerindeki Etkisinin İncelenmesine Yönelik Bir Araştırma”, 1. İşletme ve Kurumsal Sosyal Sorumluluk Kongresi, Bakü-Azerbaycan.

Dickson, M. A. (2001) "Utility of No Sweat Labels for Apparel Consumers: Profiling Label Users and Predicting their Purchases", Journal Of Consumer Affairs, 35(1): 96-118.

Dinçer, M. A. M. ve Özdemir, Y. (2013) "Kurumsal Sosyal Sorumluluk Uygulamaları ve Eşbiçimlilik: On Büyük Türk Holdingi Üzerine Vaka Çalışması”, Afyon Kocatepe Üniversitesi İIBFF Dergisi, 15(2): 31-66.

Dixon-Ogbechi, B. N., Aiyeku, J. F., Haran, E. ve Jarutirasarn, P. (2013) "Marketers' Perception of Corporate Social Responsibility and the Impact on Company's Performance: A Study of Companies in the Nigerian Service Industry in Lagos Metropolis", The International Journal of Management, 1(3): 1-13.

Economics Department of Athens University of Economics and Business, (2011) "CR Theoretical Background", http://www.csrquest.net/default.aspx?articleID=13126\&heading=, (03.03.2014). 
Friedman, M. (1970) "The Social Responsibility of Business is to Increase Profits", The New York

Times Magazine, 13, http://www.colorado.edu/studentgroups/libertarians/issues/friedman-soc-respbusiness.html (25.05.2015).

Hopkins, M. (2012) “Corporate Social Responsibility and International Development: Is Business the Solution?", New York, Routhledge.

İliç, D. K. (2010) "Iş̧letmelerin Kurumsal Sosyal Sorumluluk Düzeylerinin Belirlenmesine Yönelik Bir Literatür Taraması", Ege Akademik Bakış, 10(1): 303-318.

Johnson \& Wales University Scholars Archive (2012) "The Impact of Nationality, Gender, and Education on Students' Buying Attitudes Towards Ethical and Socially Responsible Products", http://scholarsarchive.jwu.edu/cgi/viewcontent.cgi?article=1010\&context=mba_student, (12.03.2014).

Kaya, H. (2008) “Demografik Özelliklerin Kurumsal Sosyal Sorumluluk Algılaması Üzerindeki Rolü: Bandırma Yerelinde Bir Araştırma", Balıkesir Üniversitesi Sosyal Bilimler Enstitüsü Dergisi, 11(20): 96-110.

Kelley, S. W., Ferrell, O. C. ve Skinner, S. J. (1990) "Ethical Behavior among Marketing Researchers: An Assessment of Selected Demographic Characteristics", Journal of Business Ethics, 9(8): 681688.

Lamsa, A-M., Vehkapera, M., Puttonen, T. ve Pesonen, H-L. (2008) "Effect of Business Education on Women and Men Students' Attitudes on Corporate Responsibility in Society", Journal of Business Ethics, 82(1): 45-58.

Lloyd, T., Heinfeldt, J. ve Wolf, F. (2008) "Corporate Social Responsibility from the Employees' Perspective: An Empirical Organizational Analysis”, Review of Business Research, 8(3): 17-24.

Özdemir, H. Ö. (2007) "Çalışanların Kurumsal Sosyal Sorumluluk Algılamalarının Örgütsel Özdeşleşme, Örgütsel Bağlılık ve İş Tatminine Etkisi: OPET Çalışanlarına Yönelik Uygulama”, Doktora Tezi, Marmara Üniversitesi, Sosyal Bilimler Enstitüsü, İstanbul.

Paetzold, K. (2010) “Corporate Social Responsibility (CSR): An International Marketing Approach”, Hamburg, Diplomica Verlag.

Pelit, E., Keleş, Y. ve Çakır, M. (2009) "Otel İşletmelerinde Sosyal Sorumluluk Uygulamalarının Belirlenmesine Yönelik Bir Araştırma", Yönetim ve Ekonomi, 16(2): 19-30.

Peterson, D. K. (2004) "The Relationship between Perceptions of Corporate Citizenship and Organizational Commitment”, Business and Society, 43(3): 296-319.

Quazi, A. M. (2003) "Identifying the Determinants of Corporate Managers' Perceived Social Obligations", Management Decision, 41(9): 822 - 831. 
Sert, N. Y. (2012) “Türkiye’de Özel Sektörün Kurumsal Sosyal Sorumluk Anlayışına İlişkin Yarar Alg1s1: Kurumsal Sosyal Sorumluluk Faaliyetlerinin Duyurulmasinda Web Sitelerinin Kullanılması", Online Academic Journal of Information Technology, 3(9): 31-50.

Sethi, S. P. (1975) "Dimensions of Corporate Social Performance: An Analytical Framework", California Management Review, 17(3): 58-64.

Sims, R. R. (2003) “Ethics and Corporate Social Responsibility: Why Giants Fall?”, USA, Greenwood Publishing Group.

Smirnova, Y. (2012) "Perceptions of Corporate Social Responsibility in Kazakhstan", Social Responsibility Journal, 8(3): 404-417.

Stawiski, S., Deal, J. J. ve Gentry, W. (2010) "Employee Perceptions of Corporate Social Responsibility: The Implications for Your Organization", North Caroline, Center for Creative Leadership.

Tan, G. ve Komaran, R. (2006) "Perceptions of Corporate Social Responsibility: An Empirical Study in Singapore", 13th Annual International Conference on Advances in Management, LisbonPortugal.

Tuzzolino, F. ve Armandi, B. R. (1981) “A Need-Hierarchy Framework for Assessing Corporate Social Responsibility", Academy of Management Review, 6(1): 21-28.

Virvilaite, R. ve Daubaraite, A. (2011) "Corporate Social Responsibility in Forming Corporate Image”, Inzinerine Ekonomika-Engineering Economics, 22(5): 534-543.

Yam, L. H. ve Fredericks, L. J. (2009) “Demographic Antecedents of Senior Managers' Perception of Corporate Social Responsibility in the Petrochemical Industry in Malaysia", The International Journal of Environmental, Cultural, Economic and Social Sustainability, 4(6): 21-31.

Yönet, E. (2005) “Kurumsal Sosyal Sorumluluk Anlayışında Son Dönemeç: Stratejik Sorumluluk”, Sosyal Bilimler Dergisi, 8(13): 239-264. 